БАНКРУТСТВО ПІДПРИЄМСТВА: ПІДХОДИ, ПРОЦЕДУРИ ПРОВЕДЕННЯ, ОЦІНКА ПЕРСПЕКТИВ ТА ПРІОРИТЕТІВ УПРАВЛІННЯ В УМОВАХ КРИЗИ ПЛАТОСПРОМОЖНОСТІ

\author{
Bachkir I.H., \\ assistant at the department of management, \\ Kremenchuk Mykhailo Ostrohradskyi National University
}

\title{
BANKRUPTCY OF THE ENTERPRISE: APPROACHES, PROCEDURES, ASSESSMENT OF PROSPECTS AND PRIORITIES OF MANAGEMENT IN THE CONDITIONS OF SOLVENCY CRISIS
}

Постановка проблеми. В умовах кризи платоспроможності 2020 року, посиленої негативними наслідками поширення COVID-19, виникає необхідність дослідження процедур та стадій протидії банкрутству, оцінці перспектив та пріоритетів діяльності підприємств. Кризові явища характеризуються останні десять років більшим рівнем ризиків через зростаючий рівень конкуренції, глобалізацію ринків, що загрожує навіть найбільш платоспроможним та ефективним підприємствам. Кризові явища в економіці посилюються соціально-політичними проблемами, що зумовлює тиск на підприємства у можливості забезпечити стабільність доходів та підтримувати необхідний рівень платоспроможності.

Аналіз останніх досліджень і публікацій. В науковій літературі банкрутство розглядається 3 точки зору втрати платоспроможності, неможливості розрахуватися з борговими зобов'язаннями, що призводить до потреби у санації, ліквідації та визнанні банкрутом. Проте наукові публікації 2015-2019 років вводять новий підхід до розуміння банкрутства - ринковий, який трактує поняття в більш широкому розумінні як спосіб очищення ринкової економіки від збиткових підприємств. Банкрутство розглянуто у працях таких науковців, як: Абрамова А. С., Духніч О. В. [1], Воронкова Т. Є., Рибальченко Н. П. [2], Олександренко І. В., Іщук Л. І. [5], Перерва П. Г., К Кобєлєва Т. О., Товажнянський В. Л. [6], Сейсебаєва Н. Г., Топчанюк О. В. [9], Скочиляс С. М. [10], Сукрушева Г. О., Папуцин В. М. [11], Янковець Т. М., Чернюк Ю. В. [13] та ін. Проте у вказаних дослідженнях відсутній аналіз підходів до банкрутства в умовах кризи платоспроможності 2020 року. Тому актуальною проблематикою на сьогодні $€$ вивчення процедур проведення банкрутства, оцінка перспектив й пріоритетів управління підприємствами в умовах кризи.

Постановка завдання. Мета статті - визначити підходи до сутності поняття «банкрутство», розкрити зміст процедури проведення банкрутства та оцінити перспективи й пріоритети підприємств при потенційних загрозах їх діяльності.

Для досягнення мети окреслено такі завдання: 1) провести історичний аналіз поняття «банкрутство» через контекст розвитку ринкової економіки України; 2) вивчити зміст процедури банкрутства відповідно до Кодексу України з процедури банкрутства 2019 року; 3) проаналізувати перспективи та пріоритети підприємств на основі статистичного аналізу їх діяльності в умовах формування конкурентного ринкового середовища України.

Виклад основного матеріалу дослідження. Вивчення хронології трактування поняття «банкрутство» дає змогу оцінити зміну позицій та підходів до розуміння його сутності. Відтак, ринковий підхід, запропонований Олександренко І. В. та Іщук Л.І. [5], доводить, що банкрутство є природнім механізмом очищення економіки від збиткових, неефективних підприємств (табл. 1). Сукрушева Г. О., Папуцин В.М. [11] також дотримуються такої думки: по суті, це $є$ природний механізм відбору найбільш ефективних підприємств, які володіють ресурсами для ведення діяльності в умовах кризи. Схожої думки дотримуються Воронкова Т. Є., Рибальченко Н. П. [2]: «В основі концепції банкрутства лежить просте правило вільного ринку: у конкурентному середовищі мають виживати ті підприємства, діяльність яких $€$ ефективнішою і товари яких знаходять попит споживачів». 


\section{Хронологія трактування поняття «банкрутство»}

\begin{tabular}{|c|c|c|c|}
\hline Автор, рік & Трактування поняття & Переваги & Недоліки \\
\hline 1 & 2 & 3 & 4 \\
\hline $\begin{array}{l}\text { Олександренко І. В., } \\
\text { Іщук Л. І. (2015) [5] }\end{array}$ & $\begin{array}{l}\text { Регулятор ринкової економіки, } \\
\text { завдання якого - відсіювання } \\
\text { неефективних та } \\
\text { неплатоспроможних, } \\
\text { збиткових суб’єктів } \\
\text { економічної діяльності }\end{array}$ & $\begin{array}{l}\text { В понятті відображено } \\
\text { економічну } r \text { сутність } \\
\text { банкрутства, } \text { його } \\
\text { природу та показано, } \\
\text { що банкрутство є } \\
\text { природнім регулятором } \\
\text { ринкової економіки }\end{array}$ & $\begin{array}{l}\text { Поняття розглянуто } 3 \\
\text { точки зору ринку, не } \\
\text { враховує } \\
\text { мікроекономічні } \\
\text { аспекти банкрутства }\end{array}$ \\
\hline $\begin{array}{l}\text { Янковець Т. М., } \\
\text { Чернюк Ю. В. (2016) [13] }\end{array}$ & $\begin{array}{l}\text { Банкрутство розглядається } \\
\text { як: 1) фінансова неспро- } \\
\text { можність та розорення, які } \\
\text { зумовлюють неможливість } \\
\text { підприємства розрахуватися } \\
\text { за зобов'язаннями; } \\
\text { 2) визнана в в судовому } \\
\text { порядку неспроможність } \\
\text { відновити платоспроможність } \\
\text { боржником через санацію, } \\
\text { мирові угоди відповідно } \\
\text { законодавству, використання } \\
\text { процедури ліквідації }\end{array}$ & $\begin{array}{l}\text { Визначено причини } \\
\text { банкрутства } \\
\text { (розорення, втрата } \\
\text { платоспроможності), } \\
\text { умови (судове рішення), } \\
\text { методи } \quad \text { визнання } \\
\text { підприємства } \\
\text { банкрутом (ліквідація) }\end{array}$ & $\begin{array}{l}\text { В понятті } \text { відсутні } \\
\text { першочергові } \\
\text { нефінансові причини } \\
\text { банкрутства (низький } \\
\text { рівень антикризового } \\
\text { управління, } \\
\text { наприклад) }\end{array}$ \\
\hline $\begin{array}{l}\text { Сейсебаєва Н. Г., } \\
\text { Топчанюк О. В. (2016) [9] }\end{array}$ & $\begin{array}{lr}\text { Банкрутство є } е & \text { кризовим } \\
\text { станом, що } & \text { потребує } \\
\text { спеціальних } & \text { методів } \\
\text { управління, та виникає через } \\
\text { зниження платоспроможності }\end{array}$ & $\begin{array}{l}\text { Визначено головну } \\
\text { причину - скорочення } \\
\text { платоспроможності }\end{array}$ & $\begin{array}{ll}\text { Визначення } & \\
\text { узагальнено } & \\
\text { характеризує } & \\
\text { банкрутство, } & \text { не } \\
\text { пояснює причин та } \\
\text { передумов }\end{array}$ \\
\hline $\begin{array}{l}\text { Сукрушева Г. О., } \\
\text { Папуцин В. М. (2017) [11] }\end{array}$ & 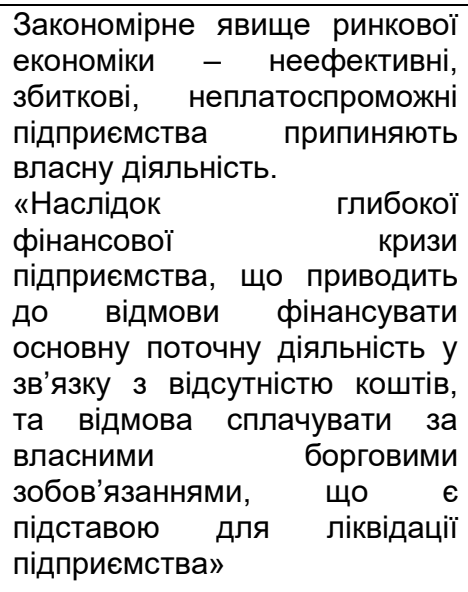 & $\begin{array}{l}\text { Визначено причини } \\
\text { (фінансова криза через } \\
\text { брак коштів) та наслідки } \\
\text { (неможливість } \\
\text { фінансування } \\
\text { діяльності, ліквідація) } \\
\text { банкрутства }\end{array}$ & $\begin{array}{lr}\text { Відсутність } & \text { умови } \\
\text { визнання } & \\
\text { підприємства } & \\
\text { банкрутом } & \\
\text { (неможливість } & \\
\text { проведення } & \text { санації, } \\
\text { укладення мирових } \\
\text { угод) }\end{array}$ \\
\hline $\begin{array}{l}\text { Воронкова Т. Є., } \\
\text { Рибальченко Н. П. (2017) } \\
\text { [2] }\end{array}$ & $\begin{array}{l}\text { Банкрутство }- \text { «це } \\
\text { основоположна, правова } \\
\text { категорія економіки України», } \\
\text { «неплатоспроможність } \\
\text { боржника та непогашення } \\
\text { зобов'язань» }\end{array}$ & $\begin{array}{l}\text { Поняття трактується } 3 \\
\text { класичної точки зору } \\
\text { через } \\
\text { «неплатоспроможність» }\end{array}$ & $\begin{array}{l}\text { Поняття } \\
\text { розглядається у у } \\
\text { широкому контексті як } \\
\text { правова категорія }\end{array}$ \\
\hline Скочиляс С. М. (2018) [10] & $\begin{array}{lr}\text { «Банкрутство характеризує } \\
\text { неспроможність підприємства } \\
\text { задовільнити вимоги } \\
\text { кредиторів щодо сплати за } \\
\text { товари, роботи та послуги, a } \\
\text { також забезпечити обов'язкові } \\
\text { платежі в бюджет і } \\
\text { позабюджетні фонди» }\end{array}$ & $\begin{array}{lr}\text { Визначено } & \text { причини } \\
\text { банкрутства } & - \\
\text { неможливість } & \\
\text { розрахуватися } & \\
\text { кредиторами } & 3\end{array}$ & $\begin{array}{l}\text { Відсутне пояснення } \\
\text { наслідків } \\
\text { неплатоспроможності }\end{array}$ \\
\hline
\end{tabular}




\begin{tabular}{|c|c|c|c|}
\hline \multicolumn{4}{|c|}{ пробовження табл. 1} \\
\hline 1 & 2 & 3 & 4 \\
\hline $\begin{array}{l}\text { Кодекс України з } \\
\text { процедур банкрутства } \\
(2019) \text { [3] }\end{array}$ & $\begin{array}{l}\text { «Банкрутство - визнана } \\
\text { господарським судом } \\
\text { неспроможність боржника } \\
\text { відновити свою } \\
\text { платоспроможність за } \\
\text { допомогою процедури санації } \\
\text { та реструктуризації і погасити } \\
\text { встановлені у порядку, } \\
\text { визначеному Кодексом, } \\
\text { грошові вимоги кредиторів } \\
\text { інакше, ніж через } \\
\text { застосування ліквідаційної } \\
\text { процедури» }\end{array}$ & $\begin{array}{l}\text { Поняття розуміється } 3 \\
\text { класичної точки зору, } \\
\text { враховує юридичні } \\
\text { підстави банкрутства }\end{array}$ & $\begin{array}{l}\text { Поняття не враховує } \\
\text { ринкових механізмів } \\
\text { та принципів } \\
\text { ринкового } \\
\text { середовища } \\
\text { діяльності } \\
\text { підприємства }\end{array}$ \\
\hline
\end{tabular}

Джерело: сфрормовано автором на основі [2-3; 5; 9-11; 13]

Янковець Т. М., Чернюк Ю. В. [13] розглядають банкрутство з точки зору внутрішньої фрінансової неспроможності розрахунку за борговими зобов'язаннями, умови, за якої підприємство визнається банкрутом (судове рішення, неможливість проведення санації, укладення мирових угод, потреба у процедурі ліквідації). Такий підхід чітко визначає інструменти подолання банкрутства, проте не враховує першопричини банкрутства. Для прикладу, такими причинами можуть бути неефективність антикризового менеджменту: відсутність управління дебіторською заборгованістю, моніторингу фінансового стану дебіторів, прогнозування ризиків, прогнозування доходів та витрат, грошових потоків, розуміння макроекономічних трендів тощо. Як зазначають Абрамова А. С., Духніч О.В. [1], «непідготовленість до раптових кризових умов чи будь-яких інших змін у економіці» зумовлює фінансовий крах підприємств.

Сукрушева Г. О., Папуцин В.М.[11] провели систематизацію поняття «банкрутство», що дозволяє сформувати головні умови визнання підприємства банкрутом:

1. Юридичні підстави, зокрема визнання судом нездатності розрахуватися за борговими зобов'язаннями, що підтверджується документально.

2. Неможливість розрахуватися з кредиторами у визначені документально терміни.

3. Неможливість проведення санації чи мирових угод.

4. Потреба у проведенні ліквідації.

5. Неможливість антикризових заходів подолати фінансову неспроможність та визнання підприємством власної фінансової неспроможності.

Отже, вивчення сутності поняття «банкрутство» дає підстави стверджувати, що, на противагу класичному підходу до розуміння терміну, новий ринковий підхід, який зароджується в науковій літературі, розглядає поняття у широкому контексті як спосіб очищення економіки від неплатоспроможних, неефективних підприємств. Класичний підхід трактує поняття через неможливість розрахуватися з кредиторами своєчасно, що засвідчується документально через судові процедури визнання банкрутом.

Не зважаючи на різні причини банкрутства підприємств у все більш мінливих умовах зовнішнього середовища, в науковій літературі та законодавстві трактування поняття практично не змінилося, а юридичні підстави є головними передумовами визнання банкрутом.

У 2019 році в Україні прийнято Кодекс з процедури банкрутства [3], в якому визначено заходи протидії банкрутству (повідомлення про ознаки засновників, власників, надання фінансової допомоги, санація боржника для відновлення платоспроможності через організаційно-господарські, управлінські, інвестиційні, технічні, фрінансово-економічні, правові заходи). Санація $€$ системою заходів, що попереджує банкрутство та є етапом, що може запобігти банкрутству, відповідно плану санації. План санації включає «розміри, порядок і строки погашення вимог кредиторів, які беруть участь у санації; заходи щодо виконання плану санації та нагляду за виконанням плану санації; обсяг повноважень керуючого санацією (у разі його призначення)» [3]. Ліквідаційний аналіз додається до плану для підтвердження потенційних вигід санації для кредиторів, що підтверджується фрінансовим аналізом підприємства. План санації затверджується Господарським судом [3].

До боржника можуть застосовуватися процедури розпорядження майном, санації та ліквідації. Підставою для відкриття справи про банкрутство $є$ заява боржника або кредитора у разі загрози неплатоспроможності. Для проведення санації або ліквідації призначається арбітражний керуючий (суб'єкт незалежної професійної діяльності) [3].

Кодекс з процедури банкрутства передбачає проведення процедури банкрутства, що включає процедури відкриття справи, розпорядження майном, санації, ліквідаційні процедури (наслідки визнання банкрутом, функції господарського суду, повноваження ліквідатора та звітність, ліквідаційну масу, продаж майна та черговість задоволення вимог кредиторів, звільнення працівників та зберігання 
документів), закриття провадження, інші процедури. Важливо відмітити, що у кодексі передбачено відновлення платоспроможності фрізичної особи, реструктуризацію боржників [3].

Аналіз наукової літератури свідчить про те, що збитковість $€$ передумовою виникнення кризових ситуацій, неплатоспроможності та банкрутства. Статистичні дані (табл. 2) вказують на те, що в період економічного спаду 2016 року частка збиткових підприємств машинобудування склала $37,7 \%$, в період економічного пожвавлення 2017-2019 років показник скоротився до рівня 25,2\% - 24,8\%, тоді як криза платоспроможності 2020 року зумовила зростання збитковості до рівня 46,7\% підприємств (лише за три місяці 2020 року).

Таблиця 2

Динаміка фрінансових результатів до оподаткування великих та середніх підприємств машинобудування у 2016-2020 рр., млн грн

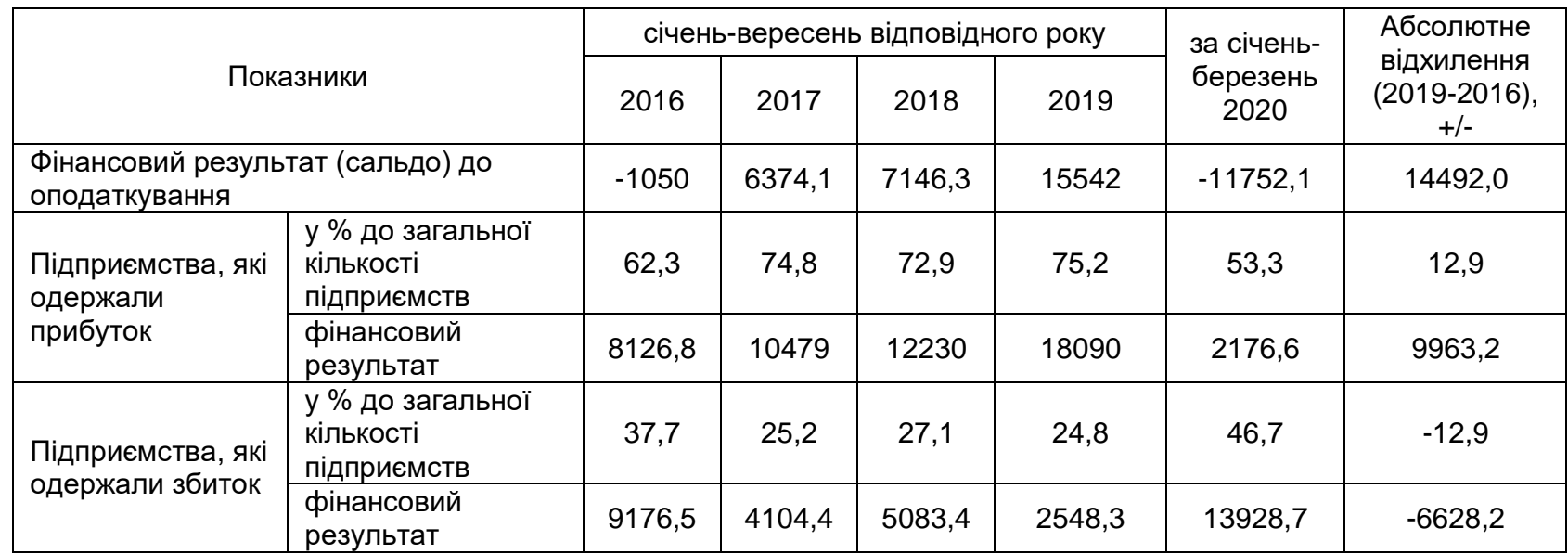

Джерело: [12]

У період економічної стагнації (2015-2016 рр.) фінансовий результат був від'ємний (наприклад, 1050 млн грн у 2016 році), тоді як економічне зростання 2017-2019 років забезпечило зростання фрінансових результатів. Криза платоспроможності 2020 року відразу позначилася на рівні прибутковості через різке скорочення фрінансових результатів - отримано збиток в розмірі 11752,1 млн. грн. Порівняння фінансових результатів машинобудування та інших видів економічної діяльності доводить, що в період кризи збитковість суттєво зростає та характерна для більшої частки підприємств (40,8\% в цілому для всіх підприємств різних видів діяльності у січні-березні 2020 року, порівняно з 22,7\% у січні-вересні 2019 року, 29,6\% у січні-вересні 2018 року, 29,1\% у січні-вересні 2017 року, 35,8\% у січні-вересні 2016 року). Найбільше страждають від зростання збитковості такі галузі, як сільське, лісове та рибне господарство, промисловість, оптова та роздрібна торгівля; ремонт автотранспортних засобів і мотоциклів, операції з нерухомим майном, профресійна, наукова та технічна діяльність (табл. 3).

Таблиця 3

Динаміка фінансових результатів до оподаткування великих та середніх підприємств за видами економічної діяльності України у 2016-2020 рр., млн грн

\begin{tabular}{|c|c|c|c|c|c|c|c|}
\hline \multirow{2}{*}{$\begin{array}{c}\text { Фінансовий результат } \\
\text { (сальдо) до } \\
\text { оподаткування }\end{array}$} & \multicolumn{4}{|c|}{ За січень-вересень відповідного року } & \multirow{2}{*}{$\begin{array}{l}\text { за січень- } \\
\text { березень } \\
2020 \text { року }\end{array}$} & \multirow{2}{*}{$\begin{array}{c}\text { Абсолютне } \\
\text { відхилення } \\
\text { (2019-2016), } \\
+/- \\
\end{array}$} & \multirow{2}{*}{$\begin{array}{c}\text { Темп } \\
\text { приросту } \\
(2019 / 2016 \\
\text { ), \% }\end{array}$} \\
\hline & 2016 & 2017 & 2018 & 2019 & & & \\
\hline 1 & 2 & 3 & 4 & 5 & 6 & 7 & 8 \\
\hline Усього & 85708 & 222209 & 196532 & 342810 & $-4902,6$ & 257102 & 299,97 \\
\hline $\begin{array}{l}\text { сільське, лісове та рибне } \\
\text { господарство }\end{array}$ & $-828,2$ & 54,4 & 115,8 & $-43,3$ & $-158,7$ & $-784,9$ & $-94,77$ \\
\hline промисловість & 2645,7 & 96140,6 & 99871,9 & 155396 & -66115 & 152750 & 5773,53 \\
\hline будівництво & $-68,7$ & 1025,4 & 1555,2 & 3638,3 & $-701,1$ & 3569,6 & - \\
\hline $\begin{array}{l}\text { оптова та роздрібна } \\
\text { торгівля; ремонт } \\
\text { автотранспортних засобів } \\
\text { і мотоциклів }\end{array}$ & 6691,1 & 29868,5 & 31294 & 65600 & -10953 & 58908,9 & 880,41 \\
\hline $\begin{array}{l}\text { транспорт, складське } \\
\text { господарство, поштова та } \\
\text { кур'єрська діяльність }\end{array}$ & 10497 & 10781 & -16651 & 8171,9 & -27748 & $-2325,1$ & $-22,15$ \\
\hline
\end{tabular}




\begin{tabular}{|c|c|c|c|c|c|c|c|}
\hline & & & & & & \multicolumn{2}{|c|}{ продовження табл. 3} \\
\hline 1 & 2 & 3 & 4 & 5 & 6 & 7 & 8 \\
\hline $\begin{array}{l}\text { тимчасове розміщування } \\
\text { й організація харчування }\end{array}$ & $-353,2$ & 564,1 & 730,9 & 2603,8 & $-2226,2$ & 2250,6 & - \\
\hline $\begin{array}{l}\text { інформація та } \\
\text { телекомунікації }\end{array}$ & 1569,1 & 10734,5 & 11516,6 & 16940,9 & 326,3 & 15371,8 & 979,66 \\
\hline $\begin{array}{l}\text { фрінансова та страхова } \\
\text { діяльність }\end{array}$ & 39419 & 39580,9 & 39434,9 & 46268,6 & 112530 & 6849,6 & 17,38 \\
\hline $\begin{array}{l}\text { операції з нерухомим } \\
\text { майном }\end{array}$ & -4548 & 972,7 & 2397,2 & 11020,6 & $-9309,3$ & 6472,6 & - \\
\hline $\begin{array}{l}\text { професійна, наукова та } \\
\text { технічна діяльність }\end{array}$ & 29784 & 31936,7 & 24588,7 & 30005,6 & 1538,2 & 221,6 & 0,74 \\
\hline $\begin{array}{l}\text { діяльність у сфері } \\
\text { адміністративного та } \\
\text { допоміжного } \\
\text { обслуговування }\end{array}$ & 704,1 & 1487,3 & 1427,4 & 2300,5 & $-956,2$ & 1596,4 & 226,73 \\
\hline освіта & - & - & - & $-2,7$ & $-34,2$ & $-2,7$ & - \\
\hline $\begin{array}{l}\text { охорона здоров'я та } \\
\text { надання соціальної } \\
\text { допомоги }\end{array}$ & 7,4 & 181,5 & 141,4 & 378,6 & $-470,1$ & 371,2 & 5016,22 \\
\hline $\begin{array}{l}\text { мистецтво, спорт, } \\
\text { розваги та відпочинок }\end{array}$ & 83 & $-1105,6$ & 58,5 & 416,9 & $-623,6$ & 333,9 & 402,29 \\
\hline $\begin{array}{l}\text { надання інших видів } \\
\text { послуг }\end{array}$ & - & - & - & 113,9 & $-2,3$ & - & - \\
\hline
\end{tabular}

\section{Джерело: [12]}

В цілому за 2016-2019 роки відбулося зростання фінансових результатів до оподаткування великих та середніх підприємств. При цьому, у січні-березні 2020 року було зафіксовано фінансові результати до оподаткування у вигляді збитку в розмірі 4902,6 млн. грн. При цьому галузь діяльності впливає на рівень платоспроможності. Наприклад, сектор інформації та телекомунікацій отримав позитивний фрінансовий результат (326,3 млн грн у січні-березні 2020 року), фрінансова та страхова діяльність забезпечили ріст фрінансових результатів до рівня 112530 млн. грн, професійна, наукова та технічна діяльність - до рівня 1538,2 млн грн, тоді як інші сектори економіки характеризувалися різким скороченням прибутковості.

За даними дослідження Сукрушевої Г. О., Папуцина В. М. [11] щодо кількості справ про відновлення платоспроможності боржників або визначення їх банкрутом в період з 2011 по 2016 рік, кількість справ, закінчених провадженням, суттєво скоротилася: у 2011 році становила 10382, у 2012 7583, у 2013 - 5697, у 2014 - 3324, у 2015 - 2406, у 2016 - 2101. Загальна кількість справ, у яких винесено постанови про визнання банкрутом, у звітному періоді також скоротилася: у 2011 році становила 6745, у 2012 - 4631, у 2013 - 3359, у 2014 - 2095, у 2015 - 1799, у 2016 - 1385 [4]. 3 a даними реєстру Оприлюднення відомостей про справи про банкрутство [8] за період 01.01.2020 03.09.2020 оприлюднено 753 справи про банкрутство, а за період 01.01.2019 - 03.09 .2019 - 7457 справ. Варто відмітити, що процедури визнання банкрутом тривають роками. Для прикладу, 28.09.2016 року було оприлюднено повідомлення про прийняття до розгляду заяви про затвердження плану санації боржника до порушення провадження у справі про банкрутство ПАТ «Дашуківські бентоніти», а 14.08.2020 року - про поновлення провадження у справі про банкрутство у зв'язку 3 визнанням мирової угоди недійсною або ії̈ розірвання [7].

Зважаючи на аналітичні дані, можна визначити наступні перспективи підприємств при потенційних загрозах їх діяльності в умовах кризи платоспроможності 2020 року: проблеми забезпечення стабільного росту доходу через скорочення платоспроможності дебіторів у наступні 2-3 роки; утримання збитковості підприємств на рівні 30-60\% в найближчі 2-3 роки залежно від сектору фрункціонування; зростання кількості банкрутів у найближчі 2-3 роки через неплатоспроможність 2020-2021 років; поява нових підприємств у різних галузях економіки України через можливості, які виникають в кризових ситуаціях (наприклад, страхування та фрінансова діяльність).

Пріоритетами в діяльності підприємств, зважаючи на скорочення платоспроможності та доходів, можна вважати: контроль дебіторської заборгованості клієнтів; перегляд угод з покупцями для виявлення найбільш вірогідних ризиків у їх діяльності та договірне закріплення способів усунення ризиків; оперативне, тактичне та стратегічне планування дебіторської та кредиторської заборгованості для «очищення» від найбільш ризикованих неплатоспроможних дебіторів (наприклад, скорочення кількості клієнтів та утримання найбільш платоспроможних).

Висновки з проведеного дослідження. Проведене дослідження дає змогу зробити висновок про існування класичного та ринкового підходів до розуміння банкрутства. Класичний підхід розглядає поняття з позиції рівня платоспроможності, своєчасності розрахунків з кредиторами, юридичних 
підстав для проведення процедур банкрутства. Ринковий підхід трактує поняття з позиції механізму ринкової економіки, що забезпечує очищення від збиткових, неефективних підприємств. Процедури банкрутства займають декілька років та потребують залучення незалежних фрахівців відповідно вимогам законодавства України. В умовах сучасної кризи платоспроможності частка збиткових підприємств суттєво зросла, а тому в подальші три-п'ять років кількість банкрутств, ймовірно, зростатиме. Через це підприємства різних секторів економіки повинні розробити комплекс заходів подолання негативних наслідків кризи платоспроможності 2020 року в підсистемі управління дебіторською та кредиторською заборгованістю в першу чергу.

\section{Література}

1. Абрамова А. С., Духніч О. В. Основні причини банкрутства підприємств України та заходи по запобіганню їх неплатоспроможності. Молодий вчений. 2017. № 11. С. 1092-1095.

2. Воронкова Т. Є., Рибальченко Н. П. Банкрутство підприємства та шляхи його подолання. Інтернаука. 2017. № 2(24). Т. 2. С. 39-43.

3. Кодекс України з процедур банкрутства. Відомості Верховної Ради (ВВР). 2019. № 19. ст. 74. URL: https://zakon.rada.gov.ua/laws/show/2597-19\#Text (дата звернення: 02.08.2020).

4. Оголошення про відкриття провадження у справі про неплатоспроможність / Вищий господарський суд України. URL: http://vgsu.arbitr.gov.ua/pages/158/?d=65134\&v=7f63b5e16a\&t=6 (дата звернення: 02.08.2020).

5. Олександренко І. В., Іщук Л.І. Основні причини банкрутства підприємств. Економічний форум. 2015. № 2. С. 222-226.

6. Перерва П. Г., Кобєлєва Т. О., Товажнянський В. Л. Банкротство, санація та реструктуризація підприємства як економічні категорії антикризового управління. Вісник Національного технічного університету ХПІ. Серія: Технічний прогрес та ефективність виробництва. 2015. № 59(1168). С. 148-152.

7. Повідомлення про прийняття до розгляду заяви про затвердження плану санації боржника до порушення провадження у справі про банкрутство ПАТ «Дашуківські бентоніти» / Вищий господарський суд України. URL: http://vgsu.arbitr.gov.ua/pages/158/?d=35887\&v=bab28205f1\&t=2 (дата звернення: 02.08.2020).

8. Реєстр Оприлюднення відомостей про справи про банкрутство / Судова влада України. URL: https://supreme.court.gov.ua/supreme/pro_sud/og_pov/ (дата звернення: 02.08.2020).

9. Сейсебаєва Н. Г., Топчанюк О. В. Методи аналізу і прогнозування банкрутства підприємств. Молодий вчений. 2016. № 11(38). С. 678-681.

10.Скочиляс С. Аналіз ймовірності банкрутства підприємства. Економічний аналіз. 2008. Вип. 3(19). С. 232-234.

11.Сукрушева Г. О., Папуцин В. М. Причини та наслідки банкрутства вітчизняних підприємств у сучасних умовах. Економіка і суспільство. 2017. Випуск 9. С. 682-686.

12.Фінансові результати до оподаткування великих та середніх підприємств за видами економічної діяльності промисловості / Державна служба статистики України. URL: http://www.ukrstat.gov.ua (дата звернення: 02.08.2020).

13.Янковець Т. М., ЧернюкЮ.В.Порівняння сучасних моделей діагностики ймовірності банкрутства підприємства: закордонний та вітчизняний досвід. Інвестиції: практика та досвід. 2016. № 20. C. 58-62.

\section{References}

1. Abramova, A.S. and Dukhnich, O.V. (2017), "The main causes of bankruptcy of Ukrainian enterprises and measures to prevent their insolvency", Molodyi vchenyi, no. 11, pp. 1092-1095.

2. Voronkova, T.Ye. and Rybalchenko, N.P. (2017), "Bankruptcy of the enterprise and ways to overcome it", Internauka, no. 2(24), Vol. 2, pp. 39-43.

3. Verkhovna Rada of Ukraine (2019), "Bankruptcy Code of Ukraine", available at: https://zakon.rada.gov.ua/laws/show/2597-19\#Text (access date August 02, 2020).

4. Supreme Commercial Court of Ukraine (2020), "Announcement of the opening of insolvency proceedings", available at: http://vgsu.arbitr.gov.ua/pages/158/?d=65134\&v=7f63b5e16a\&t $=6$ (access date August 02, 2020).

5. Oleksandrenko, I.V. and Ishchuk, L.I. (2015), "The main causes of bankruptcy", Ekonomichnyi forum, no. 2, pp. 222-266.

6. Pererva, P.H., Kobielieva, T.O. and Tovazhnianskyi, V.L. (2015), "Bankruptcy, rehabilitation and restructuring of the enterprise as economic categories of crisis management", Visnyk Natsionalnoho tekhnichnoho universytetu KhPl. Seriia: Tekhnichnyi prohres ta efektyvnist vyrobnytstva, no. 59(1168), pp. 148-152. 
7. Supreme Commercial Court of Ukraine (2020), "Notice of acceptance for consideration of the application for approval of the debtor's reorganization plan before initiating bankruptcy proceedings of PJSC "Dashukivski Bentonites", available at: http://vgsu.arbitr.gov.ua/pages/158/?d=35887\&v=bab28205f1\&t=2 (access date August 02, 2020).

8. "Register of Disclosure of Information on Bankruptcy Cases", available at: https://supreme.court.gov.ua/supreme/pro_sud/og_pov/ (access date August 02, 2020).

9. Seisebaieva, N.H. and Topchaniuk, O.V. (2016), "Methods of analysis and forecasting of bankruptcy", Molodyi vchenyi, no. 11(38), pp. 678-681.

10. Skochylias, S. (2018), "Analysis of the probability of bankruptcy", Ekonomichnyi analiz, Iss. 3(19), pp. 232-234.

11. Sukrusheva, H.O. and Paputsyn, V.M. (2017), "Causes and consequences of bankruptcy of domestic enterprises in modern conditions", Ekonomika i suspilstvo, Issue 9, pp. 682-686.

12. State Statistics Service of Ukraine (2020), "Financial results before taxation of large and mediumsized enterprises by type of economic activity of industry", available at: http://www.ukrstat.gov.ua (access date August 02, 2020).

13. Yankovets, T.M. and Chernyuk, Yu.V. (2016), "Comparison of modern models of diagnostics of probability of bankruptcy of the enterprise: foreign and domestic experience", Investytsii: praktyka ta dosvid, no. 20 , pp. 58-62. 